\title{
ROK 1918 I JEGO NASTĘPSTWA W ŚWIETLE UKRAIŃSKICH PODRĘCZNIKÓW DO HISTORII: MIĘDZY POWOJENNYM URZĄDZENIEM ŚWIATA A ZAWIEDZIONYMI NADZIEJAMI UKRAIŃCÓW
}

DOI: $10.15290 /$ sp.2018.26.05

\begin{abstract}
Abstrakt. W artykule dokonano analizy ukraińskich podręczników do historii (dotychczas obowiązujących w szkole, jak i najnowszych wchodzących do użytku od roku szkolnego 2018/2019). Poszukiwano w nich treści związanych z zakończeniem pierwszej wojny światowej, ze szczególnym uwzględnieniem punktów zwrotnych wojny (rewolucji w Rosji oraz orędzia W. Wilsona), które doprowadziły do jej zakończenia oraz ich następstw (powstanie nowych państw na mapie Europy).
\end{abstract}

Słowa kluczowe: I wojna światowa, rewolucja w Rosji, orędzie Wilsona, 1918 rok, Polska, Ukraina

\begin{abstract}
The article is an analysis of the Ukrainian history textbooks (currently used at school and the latest ones coming into use from the year 2018/2019). What was searched in them was the content related to the end of World War I, with a particular consideration given to turning points of the war (Russian Revolution and W. Wilson's message) which led to its end and their consequences (creation of new states on the map of Europe).
\end{abstract}

Key words: World War I, Russian Revolution, Wilson's message, year 1918, Poland, Ukraine

W dziejach Polski, Europy i świata są daty, które stanowiły przełom i zapowiadały diametralne zmiany na przyszłość. Takim dniem jest 11 listopada 1918 r. To wówczas w Compiègne Niemcy podpisały rozejm kończący działania zbrojne pierwszej wojny światowej. Jednym narodom rok 1918 przyniósł odrodzenie państwowości, a innym jedynie zawiedzione nadzieje, jak to było w przypadku Ukraińców.

W niniejszym artykule zaprezentowano wyniki badań nad ukraińskimi podręcznikami do historii w kontekście wydarzeń, które sto lat temu doprowadziły do zakończenia pierwszej wojny światowej. W pierwszej kolejności przeanalizowano sposób prezentacji faktów oraz podejmowanych decyzji 
przez uczestników wojny. Na tym tle przyjrzano się narracji podręcznikowej w odniesieniu do "kwestii” polskiej i ukraińskiej (tak nazywano w podręcznikach ukraińskich problem starań polskich i ukraińskich o utworzenie niepodległego państwa).

Zanim zostaną zaprezentowane wyniki tej analizy, należy poczynić kilka istotnych uwag. Po pierwsze, podobnie, jak to było w czasach Związku Radzieckiego, a obecnie również w Rosji czy na Białorusi, uczniowie w ukraińskiej szkole korzystają z dwóch podręczników: jednego do historii Ukrainy («Ітсорія України»), a drugiego do historii powszechnej («Всесвітня історія»). Ten podział rzutował na przebieg analizy podręczników ukraińskich. W podręcznikach do historii powszechnej omawiane są wydarzenia związane $z$ działaniami wojennym na wschodnim i zachodnim froncie w Europie oraz poza jej granicami, a w tych pierwszych - próba utworzenia samodzielnego państwa ukraińskiego w następstwie rozpadu Cesarstwa Rosyjskiego i Austro-Węgier. Po drugie, Ministerstwo Edukacji i Nauki Ukrainy, realizując założenia reformy programowej „Nowa szkoła ukraińska” ${ }^{1}$ w roku 2018 ogłosiło konkurs na podręczniki dla klasy dziesiątej, w tym właśnie do historii Ukrainy oraz do historii powszechnej obejmujące wydarzenia z lat $1914-1945^{2}$.

Ponieważ nowe podręczniki dopiero wchodzą do użytku szkolnego, więc analizie podlegały zarówno dotychczas obowiązujące, jak i te najnow-

1 Програма для загальноосвітніх навчальних закладів: Історія України и Всесвітня історія 10-11 класи. Затверджено наказом Міністерства освіти і науки України від 14.07.2016 № 826, Міністерство освіти і науки України, https://mon.gov.ua/ua/osvita/ zagalna-serednya-osvita/navchalni-programi [dostęp: 24 VII 2018]. Zaktualizowany program jest realizowany zgodnie z zarządzeniami Ministerstwa Edukacji i Nauki Ukrainy nr 52 z dnia 13 stycznia 2017 r. i nr 201 z dnia 10 lutego 2017 r. w sprawie realizacji Koncepcji realizacji polityki państwa w zakresie reformowania ogólnego szkolnictwa średniego „Nowa szkoła ukraińska” na okres do 2029 r. Jako podstawę modernizacji przyjęto program historii roku szkolnego 2012, uwzględniający zmiany, które dokonały się w 2015 r. i w 2016 r. Program został zatwierdzony rozporządzeniem Ministerstwa Edukacji i Nauki Ukrainy z dnia 07.06.2017 № 804, Про оновлені навчальні програми для учнів 5-9 класів загальноосвітніх навчальних закладів: наказ Міністерства освіти і науки України No 804 від 07.06.2017 р., Київ 2017, http://old.mon.gov.ua/files/normative/2017-06-12/ 7561/nmo-804.pdf [dostęp: 21 VII 2018].

2 Na konkurs wpłynęły makiety podręczników: do historii powszechnej - pięć na poziomie podstawowym i jeden na poziomie profilowym (rozszerzonym) oraz trzy do „Historii Ukrainy i świata”. W Bibliotece Elektronicznej Instytutu Modernizacji Treści Kształcenia zaprezentowano elektroniczne wersje fragmentów podręczników dla klas 1, 5 i 10, Електронна бібліотека Інституту модернізації змісту освіти, https://lib.imzo.gov.ua/ handle/123456789/11 [dostęp: 23 VII 2018]. Konsultacje wersji elektronicznych podręczników odbyły się w okresie 17 kwietnia - 7 maja 2018 r. Konkurs został rozstrzygnięty, ale podręczniki do szkół trafiły dopiero w połowie października $2018 \mathrm{r}$. 
sze. Łącznie przeanalizowano 16 publikacji. Są to trzy podręczniki dotyczące historii powszechnej zespołów autorskich: Tatiany Ładiczenko i Siergieja Osmołowskiego, Pawła Polańskiego oraz Igora Szczupaka i Ludmiły Morozowej ${ }^{3}$. Zostały one wydane w latach 2010-2012 i obowiązywały do roku 2018. Od nowego roku szkolnego 2018/2019 zastąpiły je podręczniki wyłonione w konkursie. Dlatego też omawiając podręczniki ukraińskie uwzględniono najpierw dotychczasowy sposób narracji i odniesiono go do treści, jak i sposobu interpretacji wydarzeń $\mathrm{w}$ nowym programie nauczania historii $\mathrm{w}$ klasach $10-11^{4}$ oraz $w$ nowych podręcznikach, które od niedawna obowiązują w ukraińskiej szkole. Są to dwa podręczniki Oleksandra Gisema i Oleksandra Martyniuka - jeden dla klas profilowanych, a drugi dla klas o profilu podstawowym ${ }^{5}$. O. Gisem opracował jeszcze jeden podręcznik do historii powszechnej o profilu podstawowym, tym razem we współautorstwie z Natalią Soroczyńską ${ }^{6}$. Analizie podlegały także trzy kolejne podręczniki zgłoszone na konkurs: Tatiany Ładiczenko, Pawła Polańskiego oraz Igora Szczupaka ${ }^{7}$ (autorów dotychczasowych podręczników szkolnych).

Uczniowie ukraińscy, oprócz podręcznika do historii powszechnej, równolegle uczą się z drugiego podręcznika, w którym są opisane dzieje narodu i ziem ukraińskich. Dopełnienie analizy na potrzeby niniejszego artykułu stanowią dotychczas obowiązujące podręczniki do historii Ukrainy autorów: Fedira Turczenko8 ${ }^{8}$, Stanisława Kulczyckiego i Julii Lebiediewej ${ }^{9}$,

3 Т.В. Аадиченко, С.О. Осмоловский, Всесвітня історія. 10 клас, видавництво Генеза, Київ 2010-2012 [dalej: Ład-Osmo]; П. Полянський, Всесвітня історія. 10 клас, видавництво Генеза, Київ 2010-2012 [dalej: Polan]; І.Я. Щупак, А.В. Морозова, Всесвітня історія. 10 клас, видавництво Прем'єр, Запоріжжя 2010 [dalej: Szczup-Mor].

4 Програма для загальноосвітніх навчальних закладів Історія України 10-11 класи, затверджено наказом Міністерства освіти і науки України від 14.07.2016 року № 826.

5 О.В. Гісем, О.О. Мартинюк, Всесвітня історія (профільний рівень): підручник Аля 10 класу, видавництво Ранок, Харків 2018 [dalej: Gis-Mar_profil_2018]; О.В. Гісем, О.О. Мартинюк, Всесвітня історія (рівень стандарту): підручник для 10 класу, видавництво Ранок, Харків 2018 [dalej: Gis-Mar_pp_2018].

6 Н.М. Сорочинська, О.О. Гісем, Всесвітня історія (рівень стандарту): підручник Аля 10 класу, видавництво Навчальна книга - Богдан, Тернопіль 2018 [dalej: Sor-Gis_2018].

7 Т.В. Аадиченко, Всесвітня історія (рівень стандарту): підручник для 10 класу, видавництво Генеза, Київ 2018 [dalej: Ład_2018]; П. Полянський, Всесвітня історія (рівень стандарту): підручник для 10 класу, видавництво Грамота, Київ 2018 [dalej: Polan_2018]; І.Я. Шупак, Всесвітня історія (рівень стандарту): підручник для 10 класу, видавництво Орион, Київ 2018 [dalej: Szczup_2018].

8 Ф.Г. Турченко, Історія Украӥни. 10 клас, видавництво Генеза, Київ 2010-2011 [daleј: Turcz_HU_2010].

9 С.В. Кульчицький, Ю.Г. Аебедева, Історія Украӥни: підручник для 10 класу, видавництво Генеза, Київ 2010 [dalej: Kul-Leb_HU_2010]. 
Olieny Pomietun i Nestora Gupana ${ }^{10}$, a także Oleksandra Rejenta i Oliega Malija ${ }^{11}$ oraz trzy najnowsze podręczniki, w tym dotychczasowego autora Stanisława Kulczyckiego (tym razem we współautorstwie z Witalijem Własowem) ${ }^{12}$, a także Oleksandra Gisema ${ }^{13}$ oraz dwóch autorów Mariana Mudrego i Oleny Arkuszy ${ }^{14}$.

Dotychczasowe podręczniki do historii Ukrainy nie były przydatne w kontekście badań nad problemem zakończenia wojny. Za to wiele mówią o entuzjazmie społecznym dla rewolucji ukraińskiej oraz o zadowoleniu z ustanowienia władzy radzieckiej na ziemiach ukraińskich, o czym poinformowali autorzy "starych" podręczników we Wstępie ${ }^{15}$. Zdziwienie budzi podręcznik Fedira Turczenki, w którym autor napisał: „W 1917 r. rozpoczęła się rewolucja ukraińska, podczas której Ukraińcy zdobyli niepodległość, której bronili z bronią w ręku do 1921 r."16. Obok niego w użyciu szkolnym był podręcznik Stanisława Kulczyckiego i Julii Lebiediewej napisany w nowym duchu. Wprowadzeniem do niego są słowa: „Bohaterski dzień rewolucji narodowej, który rozwinął się po upadku imperiów rosyjskiego i austro-węgierskiego, dał początek Ukraińskiej i Zachodnioukraińskiej Republice Ludowej, które na krótką chwilę zjednoczyły się w jedną, demokratyczną Ukrainę. Naród, któremu odmówiono prawa do istnienia, a język był prześladowany, dostał szansę na stworzenie państwa i życie w ojczyźnie" 17 . W naszych badaniach bardziej pomocne były fragmenty pochodzące z podręczników zgłoszonych na konkurs: Oleksandra Gisema oraz Mariana Mudrego i Olieny Arkuszy. Nowością w nich jest prezentacja problemów ukraińskich na tle dziejów powszechnych, co sugeruje ich tytuł „Historia: Ukraina i świat” («Історія: Україна і світ») oraz jego ministerialna klasyfikacja: „kurs zintegrowany”.

10 О.І. Пометун, Н.М. Гупан, Історія Украйни: підручник для 10 класу, видавництво Освіта, Київ 2012 [dalej: Pom-Gup_HU_2012].

11 О.П. Реєнт, О.В. Малій, Історія Украйни 10 клас, видавництво, Генеза, Київ 2010 [daleј: Reent-Mal_HU_2010].

12 В.С. Власов, С.В. Кульчицький, Історія України (рівень стандарту): підручник для 10 класу закладів загальної середньої освіти, видавництво $\Lambda$ ітера $\Lambda$ ТА, Київ 2018 [dalej: Vlas-Kul_HU_2018].

13 О.В. Гісем, Історія: Украйна і світ (інтегрований курс, рівень стандарту): підручник для 10 класу, видавництво Ранок, Харків 2018 [dalej: Gis_HU_2018].

14 М.М. Мудрий, О.Г. Аркуша, Історія: Україна і світ (інтегрований курс, рівень стандарту): підручник для 10 класу, видавництво Генеза, Київ 2018 [dalej: Mud-Ark_HU_2018].

15 Pom-Gup_HU_2012, s. 3.

16 Turcz_HU_2010, s. 3 [wszystkie cytaty z podręczników w tłumaczeniu autorki artykułu].

17 Kul-Leb_HU_2010, s. 3. 
W podręcznikach, zarówno tych sprzed, jak po reformie programowej na Ukrainie, etapy pierwszej wojny światowej pogrupowano w cykle dwuletnie: rok 1914 - początek wojny, kampanie i działania wojenne w latach 1915-1916 oraz w latach 1917-1918. Autorzy analizowanych podręczników zaakcentowali dwa punkty przełomowe, które, ich zdaniem, przyczyniły się do zakończenia pierwszej wojny światowej - były to obie rewolucje w Rosji w roku 1917 oraz przystąpienie w tym samym roku Stanów Zjednoczonych do wojny po stronie Ententy. Tym tropem poszła więc analiza podręczników.

Przedłużające się działania wojenne i wynikające z nich osłabienie gospodarcze wywołały w Rosji niezadowolenie społeczne. To właśnie na nie zwrócili uwagę autorzy ukraińskich podręczników do historii, omawiając najpierw przebieg rewolucji lutowej, a następnie październikowej w Rosji. Stanowisku Rządu Tymczasowego (zwolennikowi kontynuacji udziału w wojnie) przeciwstawili dążenie Rady Piotrogrodzkiej do zakończenia działań wojennych „za wszelką cenę", godząc się na zawarcie pokoju bez odszkodowań i zysków terytorialnych ${ }^{18}$. Podpisanie pokoju w Brześciu Litewskim, jak podkreślano, było wynikiem bezprecedensowych oddzielnych negocjacji ${ }^{19}$, w wyniku których Niemcy zajęli ok. 800 tys. km² ziem byłego Cesarstwa Rosyjskiego, w tym tereny polskie, krajów nadbałtyckich i część białoruskich. Ponadto Rosja "musiała zawrzeć pokój” z Ukraińską Republiką Ludową ${ }^{20}$. Na kartach podręczników (zarówno tych z 2010, jak i z 2018 r.) skupiono się na rozpaczy Anglii i Francji na wieść o zawarciu tego traktatu ${ }^{21}$. Jednak w nowych podręcznikach piszący je częściej zwracali uwagę na umożliwienie Niemcom na skupieniu się na froncie zachodnim ${ }^{22}$.

Drugim punktem zwrotnym w pierwszej wojnie światowej, jak podkreślają piszący ukraińskie podręczniki szkolne do historii, było przystąpienie 6 kwietnia 1917 r. Stanów Zjednoczonych do wojny przeciwko Państwom Centralnym. Tu nastąpiło zestawienie oficjalnych i faktycznych przyczyn tej decyzji. Chęci ograniczenia niemieckiej wojny podwodnej przeciwstawiono względy ekonomiczne, wskazując na ewentualne straty dla amerykańskich korporacji w przypadku klęski państw Ententy, którym udzielano wsparcia

18 Ład-Osmo, s. 129; Szczup-Mor, s. 78; Ład_2018, s. 27 i 29; Gis-Mar_pp_2018, s. 31; Gis-Mar_profil_2018, s. 30; Szczup_2018, s. 29.

19 Ład-Osmo, s. 130; Polan, s. 88; Szczup-Mor, s. 79.

20 Gis-Mar_profil_2018, s. 33; Gis-Mar_pp_2018, s. 34; Szczup_2018, s. 29.

21 Szczup-Mor, s. 79; Ład_2018, s. 30.

22 Gis-Mar_pp_2018, s. 35; Gis-Mar_profil_2018, s. 30; Mud-Ark_HU_2018, s. 57. 
w sprzęcie i amunicji ${ }^{23}$. Ponadto Stanom Zjednoczonym zależało na osłabieniu Japonii - rywala na Wschodzie. W podręcznikach ukraińskich zmieniła się ocena 14-punktowego programu pokojowego prezydenta Wilsona. W starszych podręcznikach sugerowano uczniom, iż "wytyczył on kurs globalnego przywództwa Stanów Zjednoczonych" 24, a w najnowszych mówi się o „wizji stosunków międzynarodowych w świecie powojennym” 25 oraz o "potrzebie zmiany świata i uczynienia go lepszym, wolnym i demokratycznym" 26 . Tu wymieniane są wszystkie punkty programu Wilsona (bez ich omówienia i jakiegokolwiek komentarza), w tym punkt 13. o odrodzeniu państwa polskiego.

Zawarcie pokoju brzeskiego i zakończenie działań wojennych na froncie wschodnim nie przyczyniło się do sukcesów Niemców na froncie zachodnim, a przystąpienie Stanów Zjednoczonych po stronie Ententy zmusiło ich do rozpoczęcia rozmów pokojowych trwających od 5 października 1918 r. Autorzy podręczników dotychczas obowiązujących w szkole ukraińskiej ograniczali się właśnie do tak krótkich informacji. Jak podkreślali, dopiero wybuch rewolucji w Niemczech i abdykacja 9 listopada 1918 r. cesarza Wilhelma II sprawiły, że alianci przyspieszyli rozmowy w sprawie podpisania rozejmu i chociaż "warunki rozejmu były bardzo trudne", to rankiem 11 listopada 1918 r. w wagonie sztabowym marszałka Focha w lesie Compiègne, w pobliżu dworca kolejowego delegacja niemiecka je podpisała ${ }^{27}$.

W podręcznikach najnowszych, od niedawna obowiązujących w ukrainskiej szkole, wątek kapitulacji Niemiec znacznie rozbudowano. Jest w nich mowa o pośrednictwie $\mathrm{w}$ nieformalnych negocjacjach państw neutralnych, zwłaszcza skandynawskich, papieża Benedykta XV i cesarza Karola I, którzy przestrzegali przed środowiskami antyklerykalnymi i grożącą światu rewolucją ${ }^{28}$. Jak autorzy ukraińskich podręczników napisali, te starania nie przyniosły rezultatu, dopiero taktyka amerykańskiego prezydenta Woodrowa Wilsona okazała się skuteczna. Jego „14 punktów” stało się podstawą rozmów pokojowych, a alianci nie mieli siły, by przeciwstawić się amerykańskiej wizji

23 Ład-Osmo, s. 130; ten sam zapis powtórzony w: Ład_2018, s. 17; oraz Polan, s. 89; Szczup-Mor, s. 80; Gis-Mar_pp_2018, s. 30; Gis-Mar_profil_2018, s. 29; Sor-Gis_2018, s. 28.

Mud-Ark_HU_2018, s. 55.

27 Ład-Osmo, s. 132; Polan, s. 96; Szczup-Mor, s. 85; Szczup_2018, s. 30; Ład_2018, s. 31; Polan_2018, s. 39; Gis-Mar_profil_2018, s. 37; Gis-Mar_pp_2018, s. 37; Sor-Gis_2018, s. 32; Gis_HU_2018, s. 58; Mud-Ark_HU_2018, s. 60. 
powojennego świata i ambicjom USA bycia światowym przywódcą ${ }^{29}$. W podręcznikach, których współautorem jest Oleksandr Gisem, z dużą skrupulatnością opisano okoliczności podpisania rozejmu, podając godzinę i precyzując miejsce: „w pobliżu dworca kolejowego na stacji Redon o 11 rano 11 listopada 1918 r. oddano salwę armatnią kończącą I wojnę światową" ${ }^{30}$. To również w podręcznikach tego autora znajduje się fragment porozumienia o zawieszeniu broni między aliantami a Niemcami w lesie Compiègne ${ }^{31}$. Nieco inny zabieg zastosowała Tatiana Ładiczenko - pogrupowała postanowienia rozejmu i opisała je. Tak więc jest informacja o zobowiązaniach niemieckiej delegacji w kwestii wycofania wojska z terytoriów Belgii, Francji, Luksemburga, Alzacji i Lotaryngii, Rumunii, Austrii, Węgier, Turcji, Afryki Wschodniej, a także o przekazaniu państwom Ententy znacznej ilości broni, statków, łodzi podwodnych, samolotów, ciężarówek i samochodów oraz o tym, że strona niemiecka wyrzekała się pokoju brzeskiego, jednak bez wycofania swych wojsk z terytoriów należących do Rosji przed wojną ${ }^{32}$.

Zanim przystąpiono do omówienia paryskiej i waszyngtońskiej konferencji pokojowej, autorzy ukraińskich podręczników (tych sprzed, jak i po reformie) przypominają, iż pierwsza wojna światowa wciągnęła w swą orbitę 33 państwa, w tym 29 po stronie Ententy, a 3/4 ludności świata zostało $\mathrm{w}$ nią zaangażowane (70 mln ludzi oderwano od pracy, a wielu z nich zmobilizowano do wojska). To właśnie na stratach społecznych skupili się autorzy analizowanych podręczników do historii. Jak podsumowano, w czasie wojny zginęło ok. $10 \mathrm{mln}$ ludzi, przeszło $20 \mathrm{mln}$ zostało rannych, a tuż po wojnie (druga połowa 1918 r.) wycieńczone ludy Europy dotknęła epidemia grypy - hiszpanka ${ }^{33}$. W najnowszych podręcznikach autorzy pierwszą wojnę światową nazwali „zbrodnią przeciwko ludzkości” i licząc na emocjonalny odbiór przekazu, podkreślali straty poniesione $\mathrm{w}$ każdej rodzinie oraz na fakt, że dzieci musiały zbyt wcześnie wejść w życie dorosłe ${ }^{34}$. Zarzuty padły pod adresem obu stron konfliktu, które nałożyły restrykcje na ludność cywilną, $\mathrm{w}$ tym przymusowe zaopatrzenie dla wojska, kartkowy system rozdawnic-

29 Ibidem, s. 60.

30 Gis-Mar_pp_2018, s. 37; Sor-Gis_2018, s. 32.

31 Gis_HU_2018, s. 59; Gis-Mar_profil_2018， s. 36; Gis-Mar_pp_2018， s. 38; Sor-Gis_2018, s. 32-33.

32 Ład_2018, s. 31.

33 Ład-Osmo, s. 134; Szczup-Mor, s. 93; Ład_2018, s. 32; Gis-Mar_pp_2018, s. 39; Gis-Mar_ profil_2018, s. 37; Gis-Mar_pp_2018, s. 39; Polan_2018, s. 40 i 53.

34 Gis-Mar_pp_2018, s. 42; Gis-Mar_profil_2018, s. 39; Gis-Mar_pp_2018, s. 40-41; Polan_2018, s. 47. 
twa żywności, węgla, odzieży itp. ${ }^{35}$ Dla przeciwwagi wskazano, iż w tym samym czasie, gdy miliony ludzi straciło swoją własność, wiele międzynarodowych koncernów wzbogaciło się na zamówieniach dla wojska ${ }^{36}$. Jak zauważono, podczas gdy Rosja, Austria, Niemcy, Francja i Wielka Brytania poniosły straty $\mathrm{w}$ wyniku wojny $\mathrm{w}$ przemyśle, rolnictwie czy transporcie, to Japonia i USA pomnożyły swoje bogactwo, gdyż nie brały czynnego udziału w wojnie, a ich terytoria nie były areną działań wojennych ${ }^{37}$. Podkreślano, iż wojna nieodwracalnie przyczyniła się do zniszczenia wielu zabytków historycznych na całym świecie. Opis skutków wojny domknięto wnioskiem nad wyraz nieuzasadnionym o upadku cywilizacji europejskiej: „,W XIX i na początku XX wieku opinia publiczna była pełna optymizmu i przekonana o trwałości dokonań ludzkości, takich jak godność ludzka, poszanowanie prawa i wolności obywatelskie" 38 , a po wojnie je zatraciła.

W podręcznikach sprzed reformy wskazywano na fakt, iż bezrobocie, inflacja, rosnące podatki, głód, bieda, zubożenie mas doprowadziły do zaostrzenia stosunków społecznych i rewolucji w Rosji, w Austrii, na Węgrzech i w Niemczech ${ }^{39}$. W nowszych podręcznikach podkreślano, iż zakończenie wojny warunkowało $\mathrm{w}$ wielu krajach dojście do władzy nosicieli radykalnych ideologii: komunizmu w Rosji, faszyzmu we Włoszech i narodowego socjalizmu w Niemczech ${ }^{40}$. Ponadto, zmienił się układ sił na świecie - rewolucja w Rosji sprawiła, że przez pewien czas znalazła się ona poza kręgiem wielkich mocarstw (jak dodawano: z czasem odrodziła się w postaci ZSRR), z obiegu wypadły również Niemcy, Austro-Węgry, Bułgaria i Turcja, które dotychczas determinowały politykę światową, straciły swoją pozycję Anglia i Francja na rzecz Stanów Zjednoczonych i Japonii, przestało istnieć imperium niemieckie, rosyjskie, austriackie i osmańskie ${ }^{41}$. Zdaniem autorów najnowszych podręczników czynnikiem destabilizującym w przyszłości było pozostawienie Rosji Radzieckiej poza systemem. Zarzucono państwom zwycięskim potraktowanie jej jako zdrajcy, która zawarła pokój z wrogiem ${ }^{42}$.

35

36

37 s. 37.

38

39

40

41

42 
W ramach podsumowania padło stwierdzenie o zadowoleniu zwycięzców z faktu, że wojna się skończyła, jednak uprzedzając wydarzenia suponowano: „wojna zasiała między zwycięzcami a zwyciężonymi ziarno nienawiści, goryczy i podejrzeń" ${ }^{43}$, które stały się jedną z przyczyn wybuchu drugiej wojny światowej. Z nostalgią napisano, iż „stary świat przed 1914 r. odszedł $\mathrm{w}$ zapomnienie, a wojna pozostawiła po sobie nienawiść i podejrzliwość, które zatruły porządek świata na kolejnych dwadzieścia lat" ${ }^{\prime 4}$. Wszyscy autorzy podręczników ukraińskich zgodnie podkreślają, że traktaty zawarte z Niemcami i ich sojusznikami dwadzieścia lat później w znacznej mierze doprowadziły do wybuchu drugiej wojny światowej ${ }^{45}$.

Po takim wstępie autorzy analizowanych podręczników przechodzili do opisania rozejmu podpisanego przez Niemcy w Compiègne i przebiegu konferencji pokojowej $\mathrm{w}$ Paryżu - z reguły posługując się poetyckimi stwierdzeniami typu: „działa umilkły, a rywalizacja o podział świata przeniosła się do kancelarii i toczyła się przy stole negocjacyjnym” 46 czy „konferencja stała się najcieplejszą bitwą dyplomatyczną między wczorajszymi sojusznikami" ${ }^{47}$. Traktat pokojowy podpisany w Wersalu 28 czerwca 1919 r. zakończył pierwszą wojnę światową i otwierał nowy rozdział $\mathrm{w}$ stosunkach międzynarodowych w Europie, a traktat waszyngtoński, podpisany 6 lutego 1922 r., uregulował układ sił na kontynencie azjatyckim i afrykańskim... To już temat na kolejny artykuł w stulecie ustanowienia systemu wersalsko-waszyngtońskiego.

Rok 1918 to nie tylko zakończenie pierwszej wojny światowej, to także rozpad imperiów wielonarodowych i powstanie nowych państw w Europie - tak też zatytułowano rozdziały w ukraińskich podręcznikach do historii powszechnej. Pod tym względem niewiele zmieniło się w podręcznikach najnowszych. Zanim przystąpiono do omówienia rozpadu Imperium Osmańskiego oraz Rosyjskiego czy też Austro-Węgier, padały stwierdzenia $\mathrm{o}$ „obiektywnym i nieuniknionym procesie” $\mathrm{w}$ dążeniach do niezależności narodów żyjących w ramach mocarstw wielonarodowych, jak podkreślano: "ci ludzie byli różni w swojej kulturze, tradycjach i sposobie życia" ${ }^{48}$. Letnia ofensywa Ententy w 1918 r. i porażka Państw Centralnych na frontach

\footnotetext{
43 Polan_2018, s. 49.

44 Polan, s. 102.

45 Ibidem, s. 153-155; Ład-Osmo, s. 157-158; Szczup-Mor, s. 110; Sor-Gis_2018, s. 59; Ład_2018, s. 52 .

46 Ład-Osmo, s. 139; Szczup-Mor, s. 94; Ład_2018, s. 41.

47 Polan_2018, s. 53.

48 Ład-Osmo, s. 145.
} 
wzmogły masową dezercję z armii oraz wzrost ruchów narodowych. Tak więc pod koniec października 1918 r. likwidacja Austro-Węgier stała się faktem, a na mapie Europy 31 października 1918 r. pojawiły się dwie osobne republiki: austriacka i węgierska. Tu przystępowano do omawiania proklamacji nowych państw. W jednych podręcznikach jedynie je wymieniano ${ }^{49}$, $\mathrm{w}$ innych wyjaśniano przyczyny podejmowanych decyzji o ich utworzeniu, wskazując przy tym na interesy Francji i Wielkiej Brytanii ${ }^{50}$, a w jeszcze innych każdemu powstałemu państwu poświęcano całkiem sporo miejsca ${ }^{51}$. Tak więc na stronach ukraińskich podręczników do historii można przeczytać o utworzeniu Czechosłowacji z jednoizbowym parlamentem, Jugosławii (początkowo jako Królestwo Serbów, Chorwatów i Słoweńców), o odrodzeniu państwa polskiego powstałego wskutek upadku imperiów austro-węgierskiego, niemieckiego i rosyjskiego, o utworzeniu niezależnego państwa węgierskiego i Łotwy, Litwy, Estonii, które ogłosiły swą niepodległość oraz o powstaniu Finlandii. Skutkiem ubocznym, na który zwrócili uwagę autorzy analizowanych podręczników był fakt, że ok. $30 \mathrm{mln}$ osób stało się mniejszościami narodowymi na terenach, na których dotychczas mieszkało ${ }^{52}$. Wśród mniejszości narodowych rozproszonych w kilku państwach wymieniono, m.in. Węgrów w Rumunii (Transylwania), w Słowacji i w Jugosławii oraz Niemców w Polsce i Czechosłowacji, a także Austriaków we Włoszech czy Ukraińców i Białorusinów w Polsce ${ }^{53}$.

W jednym z najnowszych podręczników z żalem napisano: „Ukrainie, Gruzji, Azerbejdżanowi i krajom Azji Środkowej nie wystarczyło sił, aby na konferencji [w Paryżu - T.M.] uzyskać zgodę na utworzenie państw niepodległych" 54 . Ponadto w podręcznikach z 2018 r., omawiając przebieg i postanowienia pokojowej konferencji w Paryżu, podkreślano nieprzychylne nastawienie jej uczestników do Ukraińców ${ }^{55}$, w tym antyukraińską kampanię delegacji polskiej, przedstawiającą reprezentantów Ukrainy (Zachodnio-

49 Polan, s. 111-113 i powtórzone w: Polan_2018, s. 48; Gis-Mar_profil_2018, s. 37; Gis-Mar_ pp_2018, s. 39; Sor-Gis_2018, s. 33.

50 Ład-Osmo, s. 140; Szczup-Mor, s. 95.

51 Ład-Osmo, s. 144-149. To rozwiązanie zastosowano we wszystkich analizowanych najnowszych podręcznikach do historii powszechnej. W obu podręcznikach O. Gisema i O. Martyniuka wiele zdań zostało dosłownie powtórzonych (Gis-Mar_pp_2018, s. 51; Gis-Mar_2018, s. 48$)$.

52 Lad_2018, s. 52.

53 Gis-Mar_pp_2018, s. 59; Sor-Gis_2018, s. 59.

54 Polan_2018, s. 41.

55 Ład_2018, s. 43-44. 
ukraińskiej Republiki Ludowej) jako sojuszników koalicji niemiecko-austriackiej lub polityków probolszewickich ${ }^{56}$. Wśród czynników, które zadecydowały o braku zainteresowania wielkich mocarstw istnieniem niezależnego państwa ukraińskiego wymieniano: reprezentowanie Ukrainy na konferencji przez różne rządy, które nie koordynowały swoich działań, traktowanie Ukrainy jak „zarażonej” bolszewizmem, zajęcie ziem ukraińskich przez sojuszników Ententy: Polskę, Rumunię i Czechosłowację, ponadto kraje Ententy nie wybaczyły Ukrainie podpisania umowy z państwami Poczwórnego Przymierza w Brześciu ${ }^{57}$. Tak więc zakończenie pierwszej wojny światowej nie przyniosło Ukraińcom uznania niezależnego ich państwa przez świat Zachodu.

Różne próby kształtowania władzy i państwowości na ziemiach ukraińskich opisane zostały w podręcznikach do dziejów Ukrainy. Zarówno w dotychczasowych, jak i w najnowszych podręcznikach ich autorzy swoją narrację w tym zakresie zaczynają od roku 1917. Pierwsze próby tworzenia władzy ukraińskiej sięgają rewolucji w Rosji i wpływu wydarzeń w Piotrogrodzie na ukraińskie nastroje społeczne. Fedir Turczenko, nazywając rewolucję w Rosji demokratyczną, podkreślił entuzjastyczne jej przyjęcie przez „uczestników tysięcy wieców i demonstracji w miastach i wioskach na Ukrainie", które „przeniosły swe poparcie na nowe władze" 58 . W podobnym tonie pisali dwaj inni autorzy dotychczasowych podręczników do historii Ukrainy Kulczycki i Lebiediewa, wskazując na "spontaniczną organizację rad robotniczych i żołnierskich, których praca była kontrolowana przez sowiecką radę w Piotrogrodzie" 59 . Do takich wystąpień doszło w Jekaterynosławiu, Odessie, Charkowie, Połtawie, Czernihowie i wielu innych dużych miastach Ukrainy ${ }^{60}$. Zdaniem Turczenki „rewolucja na Ukrainie przekształciła się w ruch narodowo-demokratyczny", a taki stan rzeczy zaniepokoił "urzędników rosyjskich i polityków pozarządowych, którzy nie byli w stanie odpowiednio zareagować na ten potężny wybuch ukraińskiej aktywności narodowej" ${ }^{\prime \prime}$. Jak podkreślił autor tego podręcznika, co prawda władze rewolucyjne w Rosji, w myśl „Deklaracji narodów Rosji” były skłonne zaakceptować decyzje

\footnotetext{
56 Gis-Mar_pp_2018, s. 45; Gis-Mar_profil_2018, s. 48 (zapis komentarza w obu podręcznikach dosłownie powtórzony); Polan_2018, s. 55.

57 Sor-Gis_2018, s. 48-49.

58 Turcz_HU_2010, s. 142.

59 Kulcz-Lebied_HU_2010, s. 136.

60 Ibidem, s. 136; Turcz_HU_2010, s. 146; Reent-Mal_HU_2010, s. 105.

61 Turcz_HU_2010, s. 147.
} 
o samostanowieniu Finlandii i Polski, to jednak odmawiały tego prawa mieszkańcom Ukrainy. W związku z tym Ukraińcy postanowili przeprowadzić swą własną rewolucję i podjęli starania o stworzenie własnego państwa ${ }^{62}$. Szerzej na ten temat pisali Kulczycki z Lebiediewą oraz Rejent z Malijem, wskazując na działania Mychajła Hruszewskiego, Wołodymyra Wynnyczenko czy Symona Petlury ${ }^{63}$. Jak zauważyli autorzy wspomnianych podręczników, kwestia narodowa była kamieniem węgielnym rozbieżności między ukraińskimi i rosyjskimi demokratami, którzy widzieli oznaki „ukraińskiego separatyzmu". Nie mając wyjścia, politycy piotrogrodzcy byli zmuszeni do ustępstw wobec ruchu narodowowyzwoleńczego ${ }^{64}$. Problem działalności Ukraińskiej Centralnej Rady został szeroko opisany również w podręczniku Olieny Pomietun i Nestora Gupana, którzy co prawda wskazywali na fakt obrony „bliskiej każdemu Ukraińcowi idei socjalistycznej i autonomii narodowo-terytorialnej", to jednak w ramach podsumowania skonstatowali, iż przyszłość pokazała błąd takiej polityki ${ }^{65}$.

Pomimo tego, że Ukraińcy podjęli kroki w stronę stworzenia własnego państwa, to jednak ich starania nie przyniosły pozytywnego efektu ${ }^{66}$. W każdym z dotychczasowych podręczników do historii rywalizacji o władzę na ziemiach ukraińskich autorzy podręczników poświęcili całkiem sporo uwagi. Omówieniu tych wydarzeń niekiedy w podręcznikach poświęcono po 60-100 stron. Zatem szczegółowo opisano dekrety Sekretariatu Generalnego, cztery kolejne Uniwersały, hetmanat Pawlo Skoropadskiego, wojnę z wojskami polskimi w 1919 r. o terytorium Wschodniej Galicji i Zachodniego Wołynia aż po powstanie Ukraińskiej SRR.

W związku z wojną polsko-ukraińską, a zatem i polsko-bolszewicką, zarzucono stronie polskiej, iż ta doprowadziła do „likwidacji państwowości ukraińskiej", a ,jakikolwiek opór najeźdźcom został bezlitośnie stłumiony" ${ }^{67}$. Jak skonstatowali Pomietun z Gupanem: „próba stworzenia demokratycznej Ukraińskiej Republiki Ludowej zakończyła się porażką" ${ }^{68}$. Autorzy ci za taki stan rzeczy obwiniali Polaków, którzy tworząc swoje niepodległe państwo „rościli sobie prawo nie tylko do swoich ziem etnicznych, ale także sięgnęli

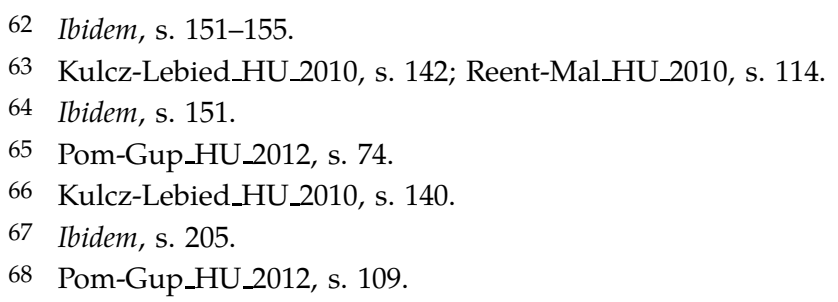


po Ukrainę, a w szczególności po Galicję Wschodnią" "69. W zaistniałej sytuacji walka narodowowyzwoleńcza na Ukrainie zakończyła się porażką, a część ziem ukraińskich została zdominowana przez siły władzy radzieckiej ${ }^{70}$. Kulczycki z Lebiediewą uznali udział sił URL w walce z RSFRR i ukraińską SRR po stronie polskiej za ",akt rozpaczy"71.

Jak Kulczycki z Lebiediewą zauważyli, po klęsce imperium austro-węgierskiego w czasie wojny światowej ukraińska ludność zachodnich regionów miała okazję zbudować własne państwo i co prawda 22 stycznia 1919 r. doszło do zawarcia unii pomiędzy Zachodnioukraińską Republiką Ludową a Ukraińską Republiką Ludową (Akt Zjednoczenia), to jednak „Ukraińcy byli jedynym narodem Austro-Węgier, który po pierwszej wojnie światowej nie był w stanie zrealizować zasady narodowego samostanowienia i stworzyć własnej państwowości"72. Przyczyn tego niepowodzenia ci autorzy upatrywali $\mathrm{w}$ niekorzystnej sytuacji międzynarodowej. Z kolei Pomietun z Gupanem podkreślali, iż podczas walki wyzwoleńczej ukształtował się sojusz militarno-polityczny z Rosją Radziecką, która „walczyła ze światowym imperializmem", a to pod koniec walki wyzwoleńczej Ukraińców doprowadziło do powstania Ukraińskiej SRR. Pod koniec 1920 r. i na początku 1921 r. podpisano traktaty - wojskowy i gospodarczy między RSFSR a Ukraińską SRR, a porozumienie między nimi było „świadomym zjednoczeniem sił w celu obrony i budowania podstaw gospodarczych obu republik"73.

Cóż z tego, że w analizowanym podręczniku padły słowa o tym, że "tendencje centralistyczne nadal rosły", a "federacja kontraktowa, powstała na początku lat 20. posiadała niewielkie wady"74, to jednak przesłanie było jednoznaczne, wskazujące na słuszność podjęcia decyzji o utworzeniu Związku Socjalistycznych Republik Radzieckich, który obejmował cztery republiki radzieckie - Federację Rosyjską, Ukraińską SRR, Białoruską SRR i Zakaukaską FSRR. Co prawda autorzy asekuracyjnie napisali, że wejście Ukraińskiej SRR do ZSRR było niejednoznacznie oceniane przez współczesnych oraz badaczy, ale nie wyjaśnili uczniom, na czym polegały te kontrowersje.

\footnotetext{
69 Ibidem, s. 124.

70 Ibidem, s. 147.

71 Kulcz-Lebied_HU_2010, s. 252.

72 Ibidem, s. 208.

73 Pom-Gup_HU_2012, s. 188.

74 Ibidem, s. 188.
} 
Przeanalizowane i omówione podręczniki ukraińskie pochodzą z $2010 \mathrm{r}$. Były one w użyciu szkolnym również $\mathrm{w}$ kolejnych latach aż po rok 2018. Dziwi ich orientacja prorosyjska wraz $\mathrm{z}$ akceptacją przemian dokonanych w czasie rewolucji bolszewickiej w Rosji, a potem i na Ukrainie. Na niedostateczne naświetlanie wydarzeń, zwłaszcza w podręcznikach do „Historii Ukrainy" niejednokrotnie wskazywali polscy członkowie Polsko-Ukraińskiej Dwustronnej Komisji Ekspertów do spraw doskonalenia treści podręczników szkolnych historii i geografii ${ }^{75}$. Zdziwienie i zaniepokojenie budzi fakt, że niejednokrotnie krytykowany przez ten zespół ekspertów, jak i autorkę niniejszego artykułu, Fedir Turczenko nadal jest autorem jednego z podręczników rekomendowanych przez Ministerstwo Oświaty do nowego programu nauczania historii na Ukrainie ${ }^{76}$.

Sposób narracji powyższych wydarzeń zmienił się w następstwie wprowadzenia do szkół nowych podręczników historii od 2018 r. Zwłaszcza podręcznik Mariana Mudrego i Oleny Arkuszy jest próbą naświetlenia dziejów ukraińskich w kontekście wydarzeń powszechnych. Dlatego też dominuje $\mathrm{w}$ nim opis wydarzeń na frontach pierwszej wojny światowej i na ich tle wskazywane są zmiany w koncepcji mocarstw walczących $\mathrm{w}$ „kwestii ukraińskiej”. Autorzy wydarzenia na Ukrainie nazwali „ukraińską rewolucją lat 1917-1921", która była częścią składową przemian społecznych i geopolitycznych w Europie Środkowo-Wschodniej ${ }^{77}$. Jak autorzy przekonują, jej przemiany sięgają XIX w., a ruch narodowowyzwoleńczy Ukrainy co prawda nie był należycie przygotowany, ale sam fakt umiędzynarodowienia sprawy ukraińskiej dawał Ukraińcom wielkie nadzieje. Tu następuje wyjaśnienie przyczyn narastania nastrojów niepodległościowych, w których uwzględniono aspekty ekonomiczne i standard życia.

Również Stanisław Kulczycki we współautorstwie z Witalijem Własowem, zanim przystąpił do omówienia prób tworzenia różnych ośrodków władzy na ziemiach ukraińskich, wyjaśnił przyczyny „rewolucji ukraińskiej"78. Ponieważ jednym z autorów w tym zespole był Kulczycki, więc podobnie, jak to uczynił ten autor $w$ podręczniku $z$ lat ubiegłych, również i teraz autorzy szkolnej narracji opisali aktywność członków ukraińskich

75 Materiały z posiedzenia Polsko-Ukraińskiej Dwustronnej Komisji Ekspertów do spraw doskonalenia treści podręczników szkolnych historii i geografii, MEN, https://www.gov.pl/ web/edukacja/polsko-ukrainska-komisja-ekspertow [dostęp: 24 II 2019]. Ф.Г. Турченко, В.М. Мороко, Історія України, 9 клас, видавництво Генеза, Київ 2017.

77 
partii robotniczych, by następnie przejść do prób ustanowienia samodzielnego państwa. Zdaniem piszących ten podręcznik powstanie Rady Centralnej z Myhajłą Hruszewskim oraz uchwalenie pierwszego Uniwersału było „punktem kulminacyjnym rewolucji ukraińskiej”, a zapis „My sami stworzymy własne życie" świadczy, zdaniem historyków, o wdrażaniu procesów budowania państwa na ziemiach ukraińskich ${ }^{79}$. Równie ważnym, zdaniem piszących ten podręcznik, był ruch wojskowo-polityczny Wolnych Kozaków wraz z Pawło Skoropadskim. Tu następuje wyjaśnienie powodów, dla których doszło do zbliżenia z Niemcami oraz uzależnienia hetmana od austro-niemieckich formacji wojskowych ${ }^{80}$.

Co wyróżnia ten podręcznik od poprzednich? Otóż, autorzy opisując wydarzenia, wyjaśniają uczniom przyczyny zapadających decyzji. Tak więc w opozycji do Skoropadskiego wskazali działania Dyrektoriatu, a po rezygnacji Wynnyczenko, Makarenko i Szweca przeszli do omówienia faktycznej władzy Petlury, który wobec niepowodzeń na froncie przeciwko bolszewikom, szukał porozumienia z Polską. Osobny rozdział w tym podręczniku zajmuje omówienie wojny ukraińsko-polskiej i jej skutków ${ }^{81}$. Ostatnim akordem niepowodzenia tworzenia samodzielnego państwa ukraińskiego było omówienie okoliczności powstania Ukraińskiej SRR ${ }^{82}$.

Chociaż przyczyn niepowodzenia utworzenia samodzielnego państwa ukraińskiego autorzy podręcznika upatrują w niekorzystnej sytuacji międzynarodowej, to jednak decyzję Symona Petlury o zawarciu sojuszu wojskowego z Drugą Rzecząpospolitą traktują jako „kamień węgielny dla umocnienia stosunków ukraińsko-polskich w epoce nowożytnej" ${ }^{83}$. Z kolei wśród następstw powstania Ukraińskiej SRR wskazują na komunistyczną ideologizację między innym w zakresie kultury. Na Ukrainie rozpoczął się szybki rozwój sieci instytucji kulturalnych i edukacyjnych, których celem była popularyzacja, rozpowszechnianie i narzucanie komunistycznych wzorców ${ }^{84}$.

Rok 1918 przyniósł natomiast odrodzenie państwa polskiego. Napisano o tym zarówno w podręcznikach z 2010, jak i 2018 r. "Odrodzenie państwa polskiego" to tytuł rozdziału w prawie wszystkich podręcznikach do histo-

\footnotetext{
79 Ibidem, s. 44.

80 Ibidem, s. 70-74.

81 Ibidem, s. 90-91.

82 Ibidem, s. 94-97, 104-105.

83 Ibidem, s. 113.

84 Ibidem, s. 116.
} 
rii powszechnej. Co istotne, teksty zawarte w podręcznikach z lat 2010-2012 w wielu przypadkach dosłownie przekopiowano do podręczników wysłanych na konkurs w roku 2018. Pisząc o odrodzeniu państwa polskiego wskazywano na upadek Austro-Węgier, Cesarstwa Niemieckiego oraz Imperium Rosyjskiego. Jako pierwsze, „ważne” wydarzenie na drodze do niepodległości Polski wskazuje się "demokratyczną rewolucję lutową w Rosji" 85 . To wówczas, zdaniem autorów analizowanych podręczników, przyznano Polakom prawo do utworzenia własnego państwa. Ich zdaniem na drodze do tego stanęły wojska niemieckie i austro-węgierskie, które zajęły ziemie wcześniej wchodzące w skład Cesarstwa Rosyjskiego. Informacja o powstaniu jesienią 1917 r. Polskiego Komitetu Narodowego, uznanego przez Ententę oficjalnym przedstawicielem Polski wprowadza w błąd niedoświadczonego czytelnika, którym jest uczeń. Nieprawdą jest, iż Komitet ten powstał na ziemiach polskich zajętych przez Państwa Centralne, a państwa Ententy potraktowały go jako prawowitą organizację polityczną. Wspominając o pokoju brzeskim napisano: „odrzucono politykę Rosji Radzieckiej w sprawie polskiej", ale nie wyjaśniono na czym ona polegała ${ }^{86}$. Co więcej, kolejne zdania w obu podręcznikach (z 2010 i z 2018 r.) zbyt ogólnie mówiły o tym, że „na początku listopada 1918 r. partie lewicowe próbowały stworzyć pierwszy rząd polski, któremu jednak nie udało się narzucić swojej władzy na wszystkich ziemiach polskich”, a „w wyniku porozumienia osiągniętego między różnymi partiami politycznymi w Warszawie 18 listopada powstał pierwszy rząd polski. Nie trwało to jednak długo, gdyż nie uzyskał wsparcia ze strony wielu partii, które uznano za rewolucyjne" ${ }^{\prime 7}$. Taki zapis nie niósł ze sobą żadnego przekazu - mamy tu do czynienia z potokiem słów bez treści.

Jedynym konkretem jest wzmianka o tym, że „przywódcą kraju” okrzyknięto Józefa Piłsudskiego, powierzając mu funkcję Naczelnika Państwa do czasu uchwalenia nowej konstytucji ${ }^{88}$. W innym podręczniku nazwano go „liderem Partii Socjalistycznej” oraz Naczelnym Dowódcą Wojska Polskiego, błędnie tytułując "prezydentem" ${ }^{89}$. W podręczniku z 2018 r., obok portretu Piłsudskiego, znalazł się cytat niepowiązany z pozostałymi treściami: „Prze-

\footnotetext{
85 Ład-Osmo, s. 146; Ład_2018_s. 35. Przywołany cytat pochodzi z obu podręczników i jest identyczny, dosłownie powtórzony.

86 Ład-Osmo, s. 146; Ład_2018, s. 36.

87 Ład-Osmo, s. 146; Ład_2018, s. 36.

88 Ład-Osmo, s. 146; Ład_2018, s. 36.

89 Szczup-Mor, s. 103.
} 
grana jest wtedy, gdy wskutek niej zrezygnujesz. A jeśli nie zrezygnujesz, to tylko chwilowa porażka" 90 .

Znacznie lepiej wypadają podręczniki Pawła Polańskiego oraz Igora Szczupaka. Przypomnijmy, ten drugi jest również twórcą podręcznika, który wszedł do szkół od nowego roku szkolnego 2018/2019. Obaj wspomniani autorzy dali uczniom uporządkowaną, chociaż z licznymi błędami, informację na temat kształtowania się władzy w Polsce, poczynając od prezentacji dwóch orientacji politycznych (prorosyjskiej Romana Dmowskiego i orientacji nastawionej na Państwa Centralne - Józefa Piłsudskiego), poprzez Komitet Narodowy Polski (błędnie zlokalizowany w Genewie) i rząd Jędrzeja Moraczewskiego, aż po przekazanie przez Radę Regencyjną władzy Józefowi Piłsudskiemu ${ }^{91}$. Chociaż nieporozumieniem w podręczniku Polańskiego było nazwanie Romana Dmowskiego „rusofilem”, a Józefa Piłsudskiego „dyktatorem”, który „pozostawił przy władzy «czerwony» rząd z Ignacym Daszyńskim"92 (premiera pomylono z Jędrzejem Moraczewskim).

W obu podręcznikach zamieszczono portret Piłsudskiego wraz z jego biogramem, jednak nie wszystkie podane treści są poprawne. Obok informacji o utworzeniu legionów, kryzysie przysięgowym, wspomniano o koncepcji federacyjnej Polski z Ukrainą i Białorusią (błędnie nazwanej „Polską konfederacyjną"). Uproszczeniem było też obwinianie Dmowskiego o to, że na konferencji pokojowej w Paryżu zabiegał o przywrócenie granic Rzeczypospolitej z 1772 r., obejmujących "Zachodnią Ukrainę i Zachodnią Białoruś" 93.

Narrację obu podręczników na temat kształtowania granic państwa polskiego spina informacja o przekazaniu Polsce Zachodniej Ukrainy przez przedstawicieli Ententy na konferencji paryskiej 25 czerwca 1919 r. Komentarz do tej decyzji był niekorzystny dla strony polskiej. Zarzucono jej, iż pomimo obowiązku nadania Ukrainie Zachodniej autonomii wojska polskie „w lipcu 1919 r. zajęły i okupowały całą Zachodnia Galicję" 94. Wśród postanowień konferencji w Paryżu wspomniano o przyznaniu Polsce dostępu do Morza Bałtyckiego i części Prus Zachodnich z Poznaniem ${ }^{95}$ (mowa o Wielkopolsce) oraz o konieczności przeprowadzenia plebiscytu na Śląsku oraz na Warmii i Mazurach (obszaru błędnie nazwanego w podręczniku Pomo-

\footnotetext{
90 Ład_2018, s. 36.

91 Polan, s. 206-209; Szczup-Mor, s. 217.

92 Polan, s. 207.

93 Ibidem, s. 208.

94 Szczup-Mor, s. 218.

95 Ibidem, s. 218; Polan, s. 209.
} 
rzem) ${ }^{96}$. Dopełnienie stanowi prezentacja wyników wspomnianych plebiscytów oraz powstań w Wielkopolsce i na Śląsku ${ }^{97}$.

Bez jakiegokolwiek omówienia przebiegu wojny polsko-bolszewickiej padło zdanie o tym, że „koła rządzące w Polsce w 1920 r. próbowały zająć Litwę, ziemie białoruskie i ukraińskie" ${ }^{98}$. Ten zapis z 2010 r. Szczupak znacznie rozbudował w wersji z 2018 r., informując o podpisaniu traktatu pokojowego w 1921 roku i „utrzymaniu” w granicach Polski „Zachodniej Ukrainy i Zachodniej Białorusi" ${ }^{99}$. Nieprawdę napisał Polański sugerując, że Petlura, w zamian za sojusz z Polską przeciwko bolszewikom, „przekazał Polsce prawie całą Prawobrzeżną Ukrainę"100. Krzywdzące w podręczniku Szczupaka było oskarżenie o "agresywną politykę" strony polskiej wobec Zachodnioukraińskiej Republiki Ludowej ${ }^{101}$.

Chociaż oba podręczniki (Polańskiego i Szczupaka) wyróżniają się pod względem ilości przekazywanych treści, to jednak zawierają one wiele nieścisłości i przekłamań. Od najnowszych podręczników (tych z 2018 r.) oczekuje się nie tylko przynajmniej takiej samej garści informacji na temat odrodzenia państwa polskiego po pierwszej wojnie światowej, jak we wspomnianych, ale także staranniejszego ich przygotowania bez wskazanych wyżej błędów. Powinny one też uwzględniać sugestie polskich historyków pracujących w Polsko-Ukraińskiej Komisji Podręcznikowej.

\section{Zakończenie}

Jak wynika z analizy ukraińskich podręczników do historii, ich autorzy bez entuzjazmu podchodzą do skutków zakończenia pierwszej wojny światowej. Nie przyniosło ono niezależności i niepodległości Ukrainie, a i system wersalsko-waszyngtoński, w ujęciu ukraińskiej narracji podręcznikowej, od samego początku był przyczyną wybuchu kolejnej wojny światowej.

Koniec pierwszej wojny światowej jednym ludom przyniósł szansę na utworzenie własnego, niepodległego państwa - powstała wówczas Polska, Czechosłowacja, Jugosławia czy kraje bałtyckie (Litwa, Łotwa i Estonia), a innym, jak na przykład Ukraińcom zawiedzione nadzieje. Tak więc, trudno

\footnotetext{
96 Szczup-Mor, s. 218.

97 Ibidem, s. 219; Polan, s. 209.

98 Szczup-Mor, s. 103.

99 Szczup_2018, s. 29.

100 Polan, s. 209.

101 Szczup-Mor, s. 218.
} 
spodziewać się, żeby ukraińscy uczniowie w następstwie lektury szkolnych podręczników do historii z zadowoleniem świętowali setną rocznicę zakończenia pierwszej wojny światowej. W odróżnieniu od nich polscy uczniowie rok 1918 traktują nie tylko jako zakończenie wojny, ale przede wszystkim jako otwarcie nowego rozdziału w dziejach niepodległego państwa polskiego. Dla Ukraińców rok 2018 to raczej rocznica próby ustanowienia własnego państwa zakończona niepowodzeniem, a na realizację tego marzenia przyszło im czekać jeszcze 73 lata. Igor Szczupak we wstępnie do swego podręcznika, który obowiązuje w szkole od nowego roku szkolnego (2018/2019), zwrócił uwagę uczniom, iż „na początku XX wieku ruch wyzwoleńczy na Ukrainie zakończył się niepowodzeniem, ale za to pod jego koniec Ukraina stała się państwem niezależnym" 102 .

I na koniec jeszcze jedno spostrzeżenie, autorzy ukraińskich podręczników do historii mają problem z prezentacją dziejów nie tylko swoich, ale także swoich sąsiadów, w tym Polski. Uwaga ta dotyczy zarówno podręczników dotychczas będących w użyciu szkolnym, jak i tych, które właśnie trafiły do szkół. Nic dziwnego, nierzadko ich autorami są te same osoby. Nadzieję należy pokładać w nowych autorach podręczników szkolnych, jak na przykład w Igorze Szczupaku. Warte odnotowania jest spostrzeżenie tego autora o konieczności walki z mitami, w tym na temat Związku Radzieckiego oraz niezbędnym wyjaśnieniu problemów i moralnych wyborów dokonanych w przeszłości przez Ukraińców ${ }^{103}$. Ponadto, należy zgodzić się z nim, że historycy ciągle debatują nad tym, co się wydarzyło na przestrzeni XX w., a politycy zbyt często wykorzystują historię $\mathrm{w}$ walce politycznej. Różne, niekiedy sprzeczne podejście do wydarzeń z przeszłości, a nawet ich fałszowanie prowadzi do wewnętrznych oraz międzynarodowych sporów i konfliktów.

\section{Bibliografia}

Власов В.С., Кульчицький С.В., Історія Украйни (рівень стандарту): підручник для 10 класу закладів загальної середньої освіти, видавництво $\Lambda$ ітера $\Lambda$ Т $\Delta$, Київ 2018.

Гісем О.В., Iсторія: Україна і світ (інтегрований курс, рівень стандарту): підручник для 10 класу, видавництво Ранок, Харків 2018.

Гісем О.В., Мартинюк О.О., Всесвітня історія (профільний рівень): підручник для 10 класу, видавництво Ранок, Харків 2018.

102 Szczup_2018, s. 2.

103 Ibidem, s. 2. 
Гісем О.В., Мартинюк О.О., Всесвітня історія (рівень стандарту): підручник для 10 класу, видавництво Ранок, Харків 2018.

Кульчицький С.В., Аебедева Ю.Г., Історія Украйни: підручник для 10 класу, видавництво Генеза, Київ 2010.

Мадиченко Т.В., Всесвітня історія (рівень стандарту): підручник для 10 класу, видавництво Генеза, Київ 2018.

Аадиченко Т.В., Осмоловский С.О., Всесвітня історія. 10 клас, видавництво Генеза, Київ 2010-2012.

Мудрий М.М., Аркуша О.Г., Історія: Украйна і світ (інтегрований курс, рівень стандарту): підручник для 10 класу, видавництво Генеза, Київ 2018.

Полянський П., Всесвітня історія (рівень стандарту): підручник для 10 класу, видавництво Грамота, Київ 2018.

Полянський П., Всесвітня історія. 10 клас, видавництво Генеза, Київ 2010-2012.

Пометун О.І., Гупан Н.М., Історія Украйни: підручник для 10 класу, видавництво Освіта, Київ 2012.

Реєнт О.П., Малій О.В., Історія Украйни: 10 клас, видавництво, Генеза, Київ 2010.

Сорочинська Н.М., Гісем О.О., Всесвітня історія (рівень стандарту): підручник для 10 класу, видавництво Навчальна книга - Богдан, Тернопіль 2018.

Турченко Ф.Г., Історія Украйни: 10 клас, видавництво Генеза, Київ 2010.

Турченко Ф.Г., Мороко В.М., Історія Украйни: 9 клас, видавництво Генеза, Київ 2017.

Щупак І.Я., Всесвітня історія (рівень стандарту): підручник для 10 класу, видавництво Orion, Київ 2018.

Щупак І.Я., Морозова А.В., Всесвітня історія. 10 клас, видавництво Прем'єр, Запоріжжя 2010.

\section{Netografia}

Materiały z posiedzenia Polsko-Ukraińskiej Dwustronnej Komisji Ekspertów do spraw doskonalenia treści podręczników szkolnych historii i geografii, MEN, https://www.gov.pl/web/edukacja/polsko-ukrainska-komisja-ekspertow

Електронна бібліотека Інституту модернізації змісту освіти, https://lib.imzo.gov. ua/handle/123456789/11

Про оновлені навчальні програми для учнів 5-9 класів загальноосвітніх навчальних закладів: наказ Міністерства освіти і науки України № 804 віА 07.06.2017 р., Київ 2017, http://old.mon.gov.ua/files/normative/2017-06-12/75 61/nmo-804.pdf

Програма для загальноосвітніх навчальних закладів: Історія України и Всесвітня історія 10-11 класи. Затверджено наказом Міністерства освіти і науки України від 14.07.2016 № 826, Міністерство освіти і науки України, https:// mon.gov.ua/ua/osvita/zagalna-serednya-osvita/navchalni-programi 


\title{
Year 1918 and its consequences in the light of Ukrainian history textbooks: between the post-war reconstruction of the world and dashed hopes of Ukrainians
}

\begin{abstract}
Summary
Year 1918 and its consequences in the light of Ukrainian history textbooks: between the post-war reconstruction of the world and dashed hopes of Ukrainians

The article presents the results of research on the Ukrainian history textbooks in the context of events that a hundred years ago led to the end of World War I. Against this background, the textbook content has been examined with reference to the Polish and Ukrainian "issues".

The authors of the Ukrainian history textbooks first discussed the course of the revolution in Russia, and then pointed to the second, in their opinion, turning point in World War I which accelerated the end of war - the US entry into war with the Central Powers on April 6, 1917. The official and factual reasons for this decision are summarized.

The year 1918 is not only the end of World War I - it also marks the breakdown of multinational empires and emergence of new countries in Europe. The proclamations of new states, including the rebirth of the Polish state after the partitions, were recorded and discussed. The end of World War I brought some nations to the creation of their own independent states - with Poland, Czechoslovakia, Yugoslavia and the Baltic States (Lithuania, Latvia and Estonia) among them, whereas some other, including Ukrainians, experienced disappointment and dashed hopes.

According to the analysis of the Ukrainian history textbooks, their authors do not approach the end of World War I enthusiastically. It did not bring Ukraine independence and it was independence, the Versailles and the Versailles system that, in the context of the Ukrainian story about the textbooks, from the very beginning was the cause of the outbreak of the next world war.
\end{abstract}

Teresa Maresz - doktor habilitowana, profesor Uniwersytetu Kazimierza Wielkiego w Bydgoszczy. Zainteresowania badawcze: edukacja historyczna w Polsce oraz w państwach sąsiedzkich, stosunki bilateralne Polski z sąsiadami (zwłaszcza z Rosją, Ukrainą oraz Białorusią), regionalizm a globalizacja. Autorka kilku monografii oraz ponad stu artykułów naukowych.

e-mail: teresamaresz@ukw.edu.pl 